\title{
The Problematics of Transmissibility: Modern Marathi Literature vis-a-vis English and Non-Indian Languages
}

\section{SUNIL SAWANT}

\begin{abstract}
This paper proposes to study the dynamics of the nature of the linguistic-cultural osmosis between Marathi and English and between Marathi and nonindian languages. It also seeks to examine whether there is a difference between the problematics of rendering Marathi litearature into English as opposed to into nonindian languages. The inclusion of the footnotes in the translated fiction, the near non-existent audience for English theatre in India, the dearth of British or American translators have adversely affected the process of exporting Marathi literature into other Englishknowing countries. Some of the problems of Chitre's anthology of translated Modern Marathi poetry pointed out by Bhalchandra Nemade are: mistakes of English grammar, spelling errors, clumsy notes on contributors, repetition of the name of the translator page after page, unattractive cover, inadequate equivalents, hackneyed phrases, irrelevant but attractive expressions, paraphrases, wordiness, improper rhythm, loose and dazzling words, etc. Vilas Sarang draws our attention to the bothersome tendency among Marathi bilingual
\end{abstract}

Translation Today Vol. 2 No. 1 Mar. 2005 @ C CIIL 2005 
translators to substitute vivid images or metaphors with abstract, generalized ideas. A dearth of properly trained translators, a dearth of good reviewing, a dearth of critical discussion in English, a dearth of funds for commissioning translators, a dearth of readership of our translations abroad, are some of the extratextual problems that prevent the smooth spread of Modern Marathi literature elsewhere.

The colonial encounter brought in an era of translations in the Marathi literary culture. Initially, Christian missionaries such as William Carey and others, British officials such as George Jervis, Thomas Candy, and Marathi pundits such as Sadashiv Kashinath Chhatre, Hari Keshavji Pathare, Balshashtri Jambhekar, and a host of others produced a great deal of translation of English non-literary texts in Marathi. Soon the natives began to import European literary forms such as the novel, Shakespearean and other forms of drama, the personal essay, the short story, the autobiography, the sonnet and other forms of the lyric through translations and imitations. Although the majority of European and American readers were initially interested only in the import of classical Sanskrit, Persian and Arabic literature, there also emerged a tradition of translating literary works from modern Indian languages into English.

It was Justine E. Abbot, an American missionary, who did the pioneering work of translating poetry of almost all Marathi saints into English. He published in all eleven books in the series entitled The Poet-Saints of Maharashtra. They are as follows: Bhanudas (1926), Eknath (1927), Bhikshugeet Athva Anutaptakadarya (1927), Dasopant Digambar (1927), Bahinabai (1929), Stotramala (1929), Tukaram (1930), Ramdas (1932), Stories of Indian Saints, Vol I (1933), Stories of Indian Saints, Vol. II (1934), and Nectar from 
Indian Saints (1935). Justine Abbot became almost an insider to Marathi culture and tried to absorb the best in the medieval 'saint poetry' tradition of Maharashtra. (Sawant, 2002: 31-32) Abbot's lifelong translation work of Marathi saint-poets thus marked a significant shift in the cultural and literary contact between the West and Maharashtra. The tradition of translating from Marathi into English continued when some of our own bilingual authors began to render Modern Marathi literature in English. This paper proposes to study the dynamics of this interlingual and intercultural possibility in order to probe the problematics of this transfer. It also seeks to examine whether the problematics of rendering Marathi into other nonindian languages is the same as that of the Marathi-English cross-over.

To begin with, a large number of Marathi works of creative fiction has been translated into English. Ian Raeside, Lecturer in Marathi at the University of London, has translated a collection of modern Marathi short stories written by Gangadhar Gadgil, Arvind Gokhale, P. B. Bhave, Vyankatech Madgulkar, D. B. Mokashi, D. M. Mirasdar, Malatibai Bedekar and others as The Rough and the Smooth. He has also translated Garambicha Bapu by S. N. Pendse as the Wild Bapu of Garambi. Shuba Slee's translation Seven Sixes are Forty-three of Kiran Nagarkar's novel Saat Sakkam Trechalis enjoyed the rare fortune of getting published in Australia by University of Queensland Press, St. Lucia, Queensland in 1980. Jim Marselos, History Department, University of Sydney, has written a very insightful foreword to this Australian edition on the place and significance of this novel in the history of the Marathi novel. Kumud Mehta has translated P. S. Rege's Avalokita. Vilas Sarang's short stories, published in American, Canadian and English as well as Indian journals, have been published under the title The Fair Tree of Void. Such English language periodicals as Bombay Literary Review, The New Quest, Indian Literature, The Little Magazine from 
New Delhi and a host of others have rendered Marathi fiction, especially short stories, into English. Recently, Sudhakar Marathe has translated Bhalchandra Nemade's epoch-making novel Kosla as Cacoon for MacMillan India Limited. Showing his awareness of the formidable challenges in translating this novel, Marathe asserts: "The following translation must be read for what it is. And it cannot be read without either some knowledge or some sense of the novel." (Marathe in Nemade, 1997: Xv). Marathe has supplied chapter-wise footnotes at the end of the book to explain certain Maharashtrian dishes such as 'bhakri', 'bhajis', 'amti', 'shrikhand', 'shira', 'bhel', 'batatawada', 'basundi', 'laddu', 'shev-chivda', 'khichdi', etc.; relations such as 'maushi', 'aaee', 'dada', 'bhai', etc.; musical instruments such as 'tabla', 'sanai'; religious practices and figures such as 'namaskars', 'shloka', 'samadhi', 'varkaris', 'kirtanas', 'aarti', 'bhagat', 'shraddha', 'shaligram', etc.; articles such as 'pat', 'lungi', 'rangoli', 'gulal', 'kumkum', etc.; festivals such as 'pola', 'yatra'; institutions such as 'math', 'balutedars', 'tamasha', etc. Inclusion of such footnotes of course could bother the reader as he is forced to go to the end of the book each time to know something more about the Marathi word. This could be an inevitable part of the phenomenon of literary translation.

For a long time, Marathi drama had not been sufficiently represented in English translation. Shanta Shahane and Kumud Mehta translated Vijay Tendulkar's Sakharam Binder into English in 1973. Published in 1989, Three Modern Indian Plays included only one of Vijay Tendulkar's Silence, The Court is in Session translated by Priya Adarkar. This situation of poor representation of Marathi drama in English translation underwent a change during the next decade. Oxford University Press has published Five Plays of Tendulkar translated by Priya Adarkar in 1992. Today, much of recent Marathi drama written by G. P. Deshpande, Satish Alekar, Shanta Ghokale, and Mahesh Elkunchwar has been substantially translated into English. The problematics here as summed up by G N Devy is: "the audience for English theatre in India is non-existent, 
though the readership for printed English is very large." (Devy, 1993: 127) Interestingly, some plays like Ghasiram Kotwal were taken to be performed abroad. The doors for the transmission of Marathi fiction and drama through the medium of motion pictures seem to have been opened by the news of the Oscar nomination for the national award-winning Marathi movie Shwas (Breath).

Compared with fiction and drama, the terse culture-specific use of words in poetry makes it relatively difficult to achieve any adequate or definitive translation. Different rhetorical devices such as symbol, analogy, allusion, simile, or ironic counterpoint produce complexity in poetry. A poem employs a variety of influences, which are literary and cultural, historical and mythical, universal and topical. The use of a foreign language for translating it distorts some of the subtleties of native experience. Since English does not have as strong a cultural basis as a regional poetic tradition has in relation to the use of the resources of folk culture and folk tradition, poetry translation poses a series of problems and difficulties. Despite such problems of poetry translation, various attempts have been made to introduce the gallery of Marathi poets to the English-knowing readers. Besides his most outstanding translation of Tukaram's poems Says Tuka (1991), Dilip Chitre's Anthology of Marathi Poetry 1945-65 (1967) is a comprehensive collection of translated Marathi poems. Some other collections of poetic translations of this earlier period are: Krishna Chaudhari and P. S. Nerurkar's On the Pavements of Life (1973) of Narayan Surve's poems; Poems of Vinda (1975) of G. V. Karandikar; Vrinda Nabar and Nissim Ezekiel's Snake-skin and Other Poems (1975) of Indira Sant's poetry. More Poems of Vinda and $\mathrm{Om}$ are two of G. V. Karandikar's recent additions. Philip Enblom has translated P. S. Rege's poems. Ranjit Hoskote and Mangesh Kulkarni have translated Vasant Abhaji Dahake's Yogabhrashta as The Terrorist of Spirit. Dilip Chitre has translated, along with Amritanubhav, Hemant Divate's poems as 
Virus Alert. N. D. Manohar's translated poems are included in Ajanta. Arjun Dangle has edited Poisoned Bread, an anthology of Dalit writings, which includes several translations of poems written by Namdeo Dhasal, Keshav Meshram and other Dalit poets. Some periodicals have published poems written by women such as Mallika Amar Shaikh, Rajani Parulekar, Prabha Ganorkar and others. The Atlantic Quarterly has given one of its sections to Marathi poetry in English translation. Literary Olympics has published translations of Marathi poems along with Marathi script. The special issue of the Sahitya Akademi's journal Indian Literature included the crosssection of Marathi poetry. The Little Magazine edited by Antara Dev Sen has published translations of Surve, Kolatkar, Chitre, Dhasal, Dahake and others. Nowadays, Sachin Ketkar is busy translating the younger Marathi poets into English. Tehalka dot com, before its closure, had given publicity to an article on Dhasal and to his poems. The website Poetry International: India Issue has lately made available some Marathi poetry in English translation. A careful look at this phenomenon reveals that almost all translators are Maharashtrian bilinguals. Unlike in the case of some Indian languages, there has also been a dearth of a large number of native English - British or American - translators doing Marathi-English translation.

\section{II}

To understand and problematise the types of textual issues that hamper the quality of some of these translations, let us now examine the kind of reception, for example, Chitre's anthology has received from its readers, critics and reviewers. Chitre himself finds it unfortunate to quote two of Mardhekar's lines in translation (Chitre, 1967: 12). Further, after commenting on the subtle effects achieved by P. S. Rege through his rhythmical liberties in Marathi, he finds this discussion irrelevant in the context of the translations of his poems, which, he admits, "cannot achieve the musical excellence of the originals". (Chitre, 1967: 16) Adil Jussawalla, an Indian 
English poet, who reviewed the anthology in The New Quest, expresses his disappointment with 'the general absence of lyrical work in the anthology'. (Jussawalla, 1968: 109) In Teekasvayamvara, Bhalchandra Nemade, Marathi poet, critic and novelist, has made elaborate comments on the issues that attend Chitre's anthology. He calls Chitre's venture 'a programme of no importance'. He criticizes Chitre for his lopsidedness in selecting poems of a particular group. He further asserts that the tradition of Modernist poetry in Marathi is extremely sickly and will not be able to occupy any significant position in English. He points out the following in Chitre's anthology: mistakes of English grammar, spelling errors, clumsy notes on contributors, repetition of the name of the translator page after page, unattractive cover, etc. Some other irritants found by him in the actual translations of the poems are as follows: inadequate equivalents, hackneyed phrases, irrelevant but attractive expressions, paraphrases, wordiness, improper rhythm, loose and dazzling words. Some of the examples of wrong equivalents used by Chitre and others mentioned by him are: 'retard' instead of 'stunt', 'hypnosis' in place of 'stupor', 'leprous' in place of 'mangy', 'thistles' for 'bristle', 'slopes' in place of 'pods of gram', 'thick soup' in place of 'vinegar', 'in the desert' instead of 'dune', 'itch under its scalp' in place of one of 'swank, swagger, strut', 'lemon tree' in place of 'neem or margosa tree', etc. (Nemade, 1990: 100-109) Commenting on the irritating tendency to substitute vivid image or metaphor with an abstract, generalized idea, Vilas Sarang criticizes Dilip Chitre for his misleading translation of Vinda Karandikar's "You and I Run":

Truth has fled from here

In a Chariot of Gold

Each one's breast

Bears the mark of a rigid fate. 
Here, Chitre has wrongly substituted Karandikar's socialist awareness conveyed through the precise image of "the mark of a wheel" with classical fatalism by rendering it as 'the mark of a rigid fate' (Sarang, 1988: 188). Thus, Chitre, Jussawalla, Nemade and Sarang all make us aware of the difficulties of translation.

\section{III}

To turn to extra textual irritants in exporting Modern Marathi literature into English, firstly, we notice that there is a dearth of properly trained translators. About the Maharashtrian bilinguals, Vilas Sarang says that "their English is of an "official" wooden type; their grasp of contemporary, colloquial English idiom is shaky". (Sarang, 1988: 3) Good translators are few and far between. Dilip Chitre, Arun Kolatkar, Gouri Deshpande have done some excellent pioneering work, but nobody is there to follow in their footsteps. Our institutions such as libraries and colleges and universities fail to play an important role in assisting the growth of Marathi literature in English translation. The Departments of Marathi at various universities in Maharashtra are often ineffective in terms of motivating the students to undertake the work of translating Marathi literature. By and large, our students are not adequately stimulated to write, translate and in general to contribute to intellectual life.

Secondly, there is a dearth of good reviewing and a dearth of critical discussion. Critics and reviewers in the west have for obvious reasons responded more to modern Indian English literature than to modern Marathi literature. This means in other words that there is a need for a better and greater interface between modern Marathi literature and western literary cultures. Translation theoreticians, translation reviewers and translators themselves will have to evolve an engagement with the act of translation in such a way that translated works are seen as part of global literary culture. This is something, which has happened with modern Latin American literature. And what has happened in the case of Latin American 
literature needs to happen in the case of modern Marathi literature and for that matter, modern literature in any regional Indian language.

Thirdly, there is a dearth of adequate financing for commissioning translators. The publishing houses play a major role in book imports and exports. They dominate such elements as copyright policy, wholesaling and distribution networks. Exporting of literature from one language to another depends to a large extent on their ability to siphon off the best talent in terms of authors and translators, and they are better able to obtain commercial financing. Today, Marathi has to function in a national and international market dominated by English. The English language publishers and multinational firms, however, do not take initiative for translating from Marathi into English. At present, as Sujit Mukherjee has pointed out, an Indian's translation into English is not widely received in England and America.

Very rarely has a British or American publisher found an Indian translation into English acceptable. There have been several cases when a UNESCO-sponsored translation of an Indian work by an Indian could not find a publisher outside India (Mukherjee, 1976: 43).

Fourthly, there is a dearth of readership of our translations abroad. The educational market determines the nature and volume of exporting literature from one language to another. The books are bought in an educational context only when the imported material has some sort of relevance to different courses of study. Since many universities and colleges in the West prescribe at the most Indian Writing in English, there is a want of buyers of translations. Therefore, even if the export of Marathi literature receives some state support, there is no guarantee that the translated works would 
ever figure in the reading lists of the departments of languages abroad.

Noticeably there is some demand for literary translations among Indian readers of English. G. N. Devy writes,

There is at least as large, if not larger, an Indian audience for Indian English books and translations as there is for books in some major Indian languages. Besides, there is an increasing urge among regional writers to see their works translated into English which is reflected in the growth in commercial, literary and journalistic publishing devoted to Indian literature in English translation.

(Devy, 1993: 118)

All over the country, English reigns as the medium of instruction. English is the language not only of industry and business but also of all services, military and civil administration both at the centre and in the states. Indian writers in English have extensively used this language delightfully felicitously for creative purposes. Translation at least into English of any major literary work from Marathi is imperative if the rest of the country is even to be made aware of it. The minimum requirement is that the translation must sound English while at the same time of course it could creatively stretch English.

\section{IV}

What we have noticed in the context of Marathi literature in English translation is more or less true about translating from Marathi into other 'non-Indian' languages. It is quite obvious that the initiative for import ought to come from the language in which the work is to be rendered rather than be forced upon every other language. After all, the supply of literary translations corresponds to 
the demand for it. As there is little or no demand from other 'world' languages such as French, German, Spanish, etc. very few translations from Marathi into these languages have been made. Vilas Sarang's editing of the special issue of a French journal devoted to Indian literature (Europe, Jan-Feb 1982) and the publication of his short stories translated into French by Alain Nadaud in April 1988 are exceptions. Unlike English-knowing scholars, men who know French or German or Spanish well enough to undertake the work of gettibg across Modern Marathi literature into these languages are still quite rare. And our teachers of French, German, or Russian fail to be representatives of cross-cultural fertilization.

\section{$\mathbf{V}$}

To conclude, we can say that the clumsy English grammar, staccato style, the haphazard substitution of English words for Marathi ones are some of the textual irritants that often mar the quality of translations exported from Marathi into English. The relative indifference of 'non-Indian' literary cultures, the want of non-native readership, the monopoly of international firms in publishing, are some of the extra textual cumbers, which are causing the transmission problems.Despite these constraints, Modern Marathi literature needs to be exported, especially into English, so as to exert some sort of impact on the rest of our country, and if made possible by foreign readership, on the rest of the world. 


\section{REFERENCES}

Chitre, Dilip (Ed) (1967) An Anthology of Marathi Poetry (194565). Mumbai: Nirmala Sadanand Publishers.

Devy, G. N (1993) In Another Tongue: Essays on Indian English Literature. Madras: Macmillan.

Jussawalla, Adil. (1968) Way Ahead: A Review of An Anthology of Marathi Poetry (1945-65) in The New Quest, Vol. 151 April/June 1968.

Mukherjee, Sujeet. (1976) On Publishing Translations in The New Quest, Vol. 101 May/June 1976.

Nemade, Bhalchandra. (1990) Teekasvayamvara. Aurangabad: Saket.

Nemade, Bhalchandra Kosla Sudhakar Marathe (Trans.) (1997) Cocoon Chennai: MacMillan.

Sarang, Vilas. (1988) The Stylistics of Literary Translation: A Study with Reference to English and Marathi. Mumbai: The Gurudev Tagore Chair of Comparative Literature.

Sawant, Sunil. (2002) Culture Contact Between Nineteenth Century America and Maharashtra in Journal of Shivaji University, Vol. 37. 
